\title{
Distribution and sources of organic matter in surface sediments of Bohai Sea near the Yellow River Estuary, China
}

\author{
ARTICLE in ESTUARINE COASTAL AND SHELF SCIENCE · JANUARY 2015
}

Impact Factor: 2.06 · DOI: 10.1016/j.ecss.2015.09.007

CITATION

1
READS

30

1 AUTHOR:

Dongyan Liu

Chinese Academy of Sciences

165 PUBLICATIONS 1,880 CITATIONS

SEE PROFILE 


\title{
Distribution and sources of organic matter in surface sediments of Bohai Sea near the Yellow River Estuary, China
}

\author{
Dongyan Liu ${ }^{\text {a, }}{ }^{*}$, Xin Li ${ }^{\text {a, b }}$, Kay-Christian Emeis ${ }^{c}$, Yujue Wang ${ }^{\text {a }}$, Pierre Richard ${ }^{\mathrm{d}}$ \\ ${ }^{a}$ Key Laboratory of Coastal Zone Environmental Processes and Ecological Remediation, Yantai Institute of Coastal Zone Research, Chinese Academy of \\ Sciences, 264003, Yantai, Shandong, PR China \\ ${ }^{\mathrm{b}}$ University of the Chinese Academy of Sciences, 100049, Beijing, PR China \\ ${ }^{\mathrm{c}}$ Helmholtz-Zentrum Geesthacht, Institute of Coastal Research, Max-Planck-Str. 1, 21502, Geesthacht, Germany \\ ${ }^{\mathrm{d}}$ Littoral, Environment et Sociétés, UMR 7266 CNRS-Université de La Rochelle, 2 rue Olympe de Gouges, 17000, La Rochelle, France
}

\section{A R T I C L E I N F O}

\section{Article history:}

Received 12 May 2015

Received in revised form

4 September 2015

Accepted 14 September 2015

Available online 16 September 2015

\section{Keywords:}

Carbon isotope

Nitrogen isotope

Organic matter

Biogenic silica

Yellow River Estuary

\begin{abstract}
A B S T R A C T
Total organic carbon (TOC) and total nitrogen (TN) concentrations and C and N stable isotope compositions in 64 surface sediment samples from the mouth of the Yellow River (YR) and from the Bohai Sea (BS) outline the distribution and sources (terrestrial and marine) of sediment organic matter. Comparatively high TOC $(0.5-0.9 \%)$ and TN $(0.07-0.11 \%)$ concentrations in the Central BS correlate with finegrained sediments that contain high concentrations of algal-derived organic carbon (AOC) and biogenic silica (BSi). Together, they indicate a dominant contribution of autochthonous organic matter from marine primary production. Low TOC $(<0.2 \%)$ and TN $(<0.03 \%)$ contents characterize surface sediments in the Bohai Strait and are typically associated with coarse-grained sediments of low AOC and BS contents. $\delta^{13} \mathrm{C}$ values ( -21 to $-22 \%$ ) are characteristic of marine-derived organic carbon in the Central BS and the Bohai Strait, whereas a significant terrigenous contribution of $40-50 \%$ is indicated by lower values $\left(<-23 \%\right.$ ) near the YR mouth. The spatial pattern of rising $\delta^{13} \mathrm{C}$ from the YR mouth to offshore areas indicates rapid sedimentation of fluvial suspensions within the vicinity of the river mouth and in Laizhou Bay, so that only approximately $10-20 \%$ of YR-derived sediments are transported to and deposited in the Central BS and/or the Bohai Strait. At most sites, $\delta^{15} \mathrm{~N}$ values are in the typical range of marine organic matter produced from assimilation of marine nitrate by phytoplankton $(5-5.5 \%$ ), but some relatively high values (6-7.28\%) mark the southern area of the Laizhou Bay as a significant sink of anthropogenic nitrogen.
\end{abstract}

() 2015 Elsevier Ltd. All rights reserved.

\section{Introduction}

Organic matter (OM) in transitional waters (e.g., coasts and estuaries) is generally a mixture originating from allochthonous (e.g., river inputs) and autochthonous sources (e.g., marine primary production) (Meyers, 1994; Hedges et al., 1997; Tesi et al., 2007). Discrimination of OM sources is important for understanding the cycle of carbon and nitrogen in coasts and estuaries because approximately $90 \%$ of organic carbon is buried there, particularly near large river mouths (Meybeck, 1982; Hedges et al., 1997). A number of geochemical approaches (e.g., isotopes of $\mathrm{C}$ and $\mathrm{N}$, biomarkers) have been used to elucidate the sources of OM in coastal

\footnotetext{
* Corresponding author. Yantai Institute of Coastal Zone Research, CAS, 17th Chunhui Road, Laishan District, 264003, Yantai, PR China.

E-mail address: dyliu@yic.ac.cn (D. Liu).
}

and estuarine systems (e.g., Andrews et al., 1998; Ramaswamy et al. 2008). The application of $C$ and $\mathrm{N}$ isotopes relies on their sourcespecific signatures. A typical range of $\delta^{13} \mathrm{C}$ values for terrestrial $\mathrm{C}_{3}$ plants is from $-26 \%$ to $-28 \%$ and for marine phytoplankton from $-19 \%$ to $-21.9 \%$ (Fry and Sherr, 1984; Meyers, 1997), and a mixture of marine and terrestrial $\mathrm{OM}$ typically has a $\delta^{13} \mathrm{C}$ value of $-23 \%$ (Pancost and Boot, 2004). The ratio of stable nitrogen isotopes (expressed as $\delta^{15} \mathrm{~N}$ ) in marine nitrate generally ranges from $3 \%$ to $6 \%$, but sewage and manure can significantly elevate them to 10-25\% (Heaton, 1986; McClelland and Valiela, 1998; Savage, 2005).

The Yellow River (YR) is one of the world's largest rivers, and it provides approximately $50 \%$ of the freshwater discharged into the Bohai Sea (BS) every year (Wang et al., 2006). The YR plume flows northeastward into the Laizhou Bay (LB) and the Central BS, and it can even reach the Bohai Strait, impacting nutrient levels and 

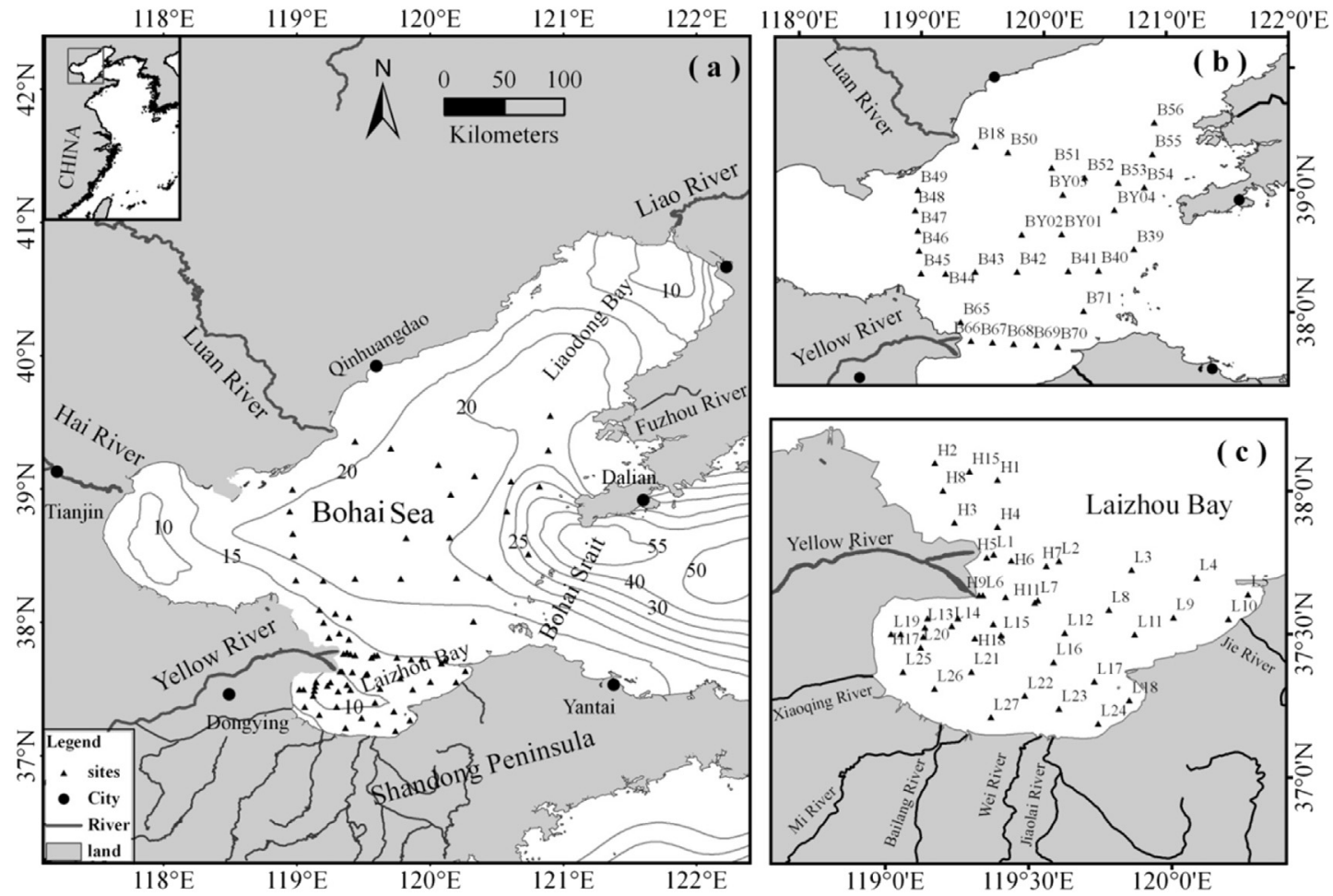

Fig. 1. Map of the Bohai Sea with water depth and sampling sites (a); sampling sites in the Central Bohai Sea (b) and Laizhou Bay (c).

affecting the thermohaline circulation and sedimentary environment in the BS (Lin et al., 2001; Wang et al., 2006). The estimated sediment discharge of the YR before 1970 was $\sim 1.08 \mathrm{Gt} \mathrm{a}^{-1}$; the discharge rapidly dropped to $\sim 0.15 \mathrm{Gt} \mathrm{a}^{-1}$ since 2000 due to reduced rainfall and artificial regulation of water and sediment discharge (Wang et al., 2006). Reduced freshwater and sediment discharge profoundly impacted the physical, biogeochemical and biological environment in the sea surrounding the delta of the YR. For example, Hu et al. (2015) estimated that the particulate organic carbon discharge of the YR has decreased from $4.11 \mathrm{Tg} \mathrm{a}^{-1}$ to $0.73 \mathrm{Tg} \mathrm{a}^{-1}$ since the $1950 \mathrm{~s}$. In addition, more than 10 continental rivers discharge into the LB. Over the last decade, intensification of agriculture and aquaculture in their catchments and in the bay has dramatically increased the nitrogen sources and inputs (Statistical Yearbook of Shandong province, 2010; Bulletin of China Ocean Environmental State, 2009-2014). For example, monitoring data (Bulletin of China Ocean Environmental State, 2009-2014) showed that the concentration of dissolved inorganic nitrogen (DIN) exceeds $28 \mu \mathrm{M}$ in approximately 30\% of bay areas; and Su et al. (2015) reported that the DIN concentrations near the YR mouth can reach up to $70 \mu \mathrm{M}$ in the summer due to increased river input. This eutrophication has resulted in frequent harmful algal blooms and the development of low oxygen environments near the sea floor (Shan et al., 2013).

The YR is a massive source of terrestrial organic carbon, but there are only limited data on organic matter distribution and origin in sediments near the YR mouth and in the adjacent shallow Bohai and Yellow Seas, although they constitute a major carbon sink of global significance (Hu et al., 2009; Lin et al., 2014). Whereas Hu et al. (2009) studied the OM distribution in the BS and noted that the YR delta and fore-delta are the main carbon sinks, there is yet no relative estimate of the proportions of allochthonous (terrigenous) and autochthonous (marine phytoplankton) material in the sediments, and little information is available on the isotopic composition of sedimentary nitrogen that would shed light on

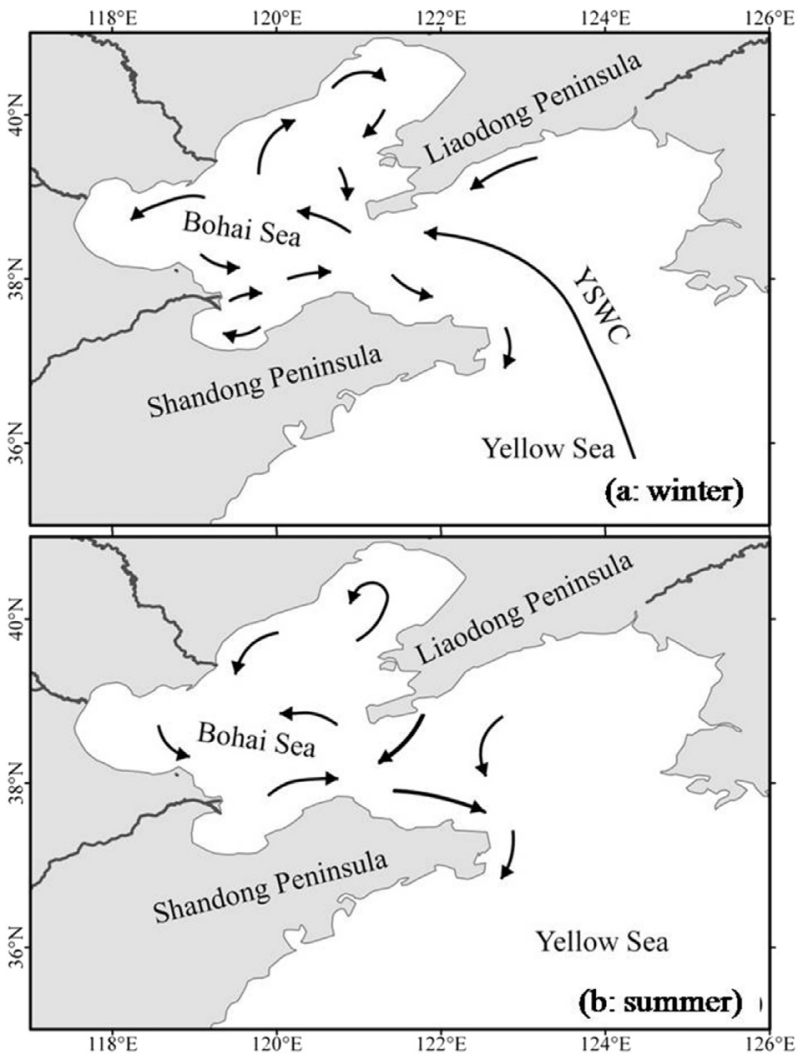

Fig. 2. Winter (a) and summer (b) circulation features in the Bohai Sea, redrawn from Guan (1994). 
Table 1

Composition and parameters of bulk organic matter and sediment grain sizes of the study area.

\begin{tabular}{|c|c|c|c|c|c|c|c|c|c|c|c|}
\hline Sampling sites & Latitude & Longitude & BSi (\%) & TOC (\%) & $\mathrm{TN}(\%)$ & $\mathrm{C} / \mathrm{N}$ & $\delta^{13} \mathrm{C}(\% 0)$ & $\delta^{15} \mathrm{~N}(\% 0)$ & Clay (\%) & Silt (\%) & Sand (\%) \\
\hline B18 & 39.358 & 119.441 & 0.5 & 0.4 & 0.05 & 9.3 & -21.9 & 6.0 & 19.7 & 45.4 & 35.0 \\
\hline B39 & 38.515 & 120.741 & 0.1 & 0.1 & 0.01 & 11.7 & -21.1 & 4.9 & 2.31 & 6.21 & 91.48 \\
\hline B40 & 38.340 & 120.450 & 0.5 & 0.4 & 0.06 & 7.8 & -21.8 & 5.4 & 11.9 & 55.5 & 32.5 \\
\hline B41 & 38.335 & 120.200 & 0.5 & 0.4 & 0.06 & 7.8 & -21.7 & 5.7 & 13.0 & 54.7 & 32.3 \\
\hline B42 & 38.331 & 119.783 & 0.4 & 0.2 & 0.03 & 7.8 & -21.7 & 5.1 & 9.05 & 56.8 & 34.2 \\
\hline BY01 & 38.637 & 120.149 & 0.7 & 0.2 & 0.04 & 5.8 & -22.1 & 5.7 & 11.5 & 21.7 & 66.8 \\
\hline BY02 & 38.636 & 119.823 & 1.0 & 0.6 & 0.07 & 10.0 & -21.5 & 5.1 & 20.3 & 60.6 & 19.1 \\
\hline B43 & 38.329 & 119.441 & 0.6 & 0.7 & 0.10 & 8.2 & -21.8 & 6.1 & 21.9 & 71.2 & 6.92 \\
\hline B44 & 38.316 & 119.200 & 0.6 & 0.6 & 0.08 & 8.8 & -22.3 & 6.3 & 21.2 & 72.1 & 6.71 \\
\hline B45 & 38.318 & 118.997 & 0.5 & 0.6 & 0.07 & 10.0 & -22.5 & 5.8 & 24.6 & 72.4 & 2.97 \\
\hline B46 & 38.502 & 118.983 & 0.9 & 0.6 & 0.08 & 8.8 & -22.3 & 5.9 & 22.1 & 73.0 & 4.96 \\
\hline B47 & 38.667 & 118.973 & 0.9 & 0.6 & 0.09 & 7.8 & -22.0 & 5.9 & 25.3 & 69.3 & 5.42 \\
\hline B48 & 38.834 & 118.951 & 0.5 & 0.4 & 0.05 & 9.3 & -22.2 & 5.6 & 20.8 & 52.7 & 26.5 \\
\hline B49 & 39.000 & 118.971 & 0.3 & 0.2 & 0.03 & 7.8 & -22.1 & 5.5 & 13.4 & 30.6 & 56.0 \\
\hline B50 & 39.308 & 119.708 & 0.7 & 0.7 & 0.10 & 8.2 & -21.8 & 5.7 & 24.4 & 68.5 & 7.09 \\
\hline B51 & 39.183 & 120.066 & 0.7 & 0.5 & 0.07 & 8.3 & -21.7 & 5.2 & 14.7 & 50.5 & 34.8 \\
\hline BY03 & 38.963 & 120.157 & 0.5 & 0.1 & 0.01 & 11.7 & -21.7 & 5.1 & 4.81 & 8.06 & 87.1 \\
\hline B52 & 39.100 & 120.337 & 0.5 & 0.2 & 0.03 & 7.8 & -21.7 & 6.9 & 9.31 & 19.6 & 71.1 \\
\hline B53 & 39.059 & 120.610 & 0.5 & 0.3 & 0.04 & 8.8 & -22.3 & 7.2 & 13.6 & 33.1 & 53.3 \\
\hline BY04 & 38.835 & 120.580 & 0.8 & 0.3 & 0.04 & 8.8 & -22.4 & 5.7 & 15.5 & 37.0 & 47.5 \\
\hline B54 & 39.022 & 120.823 & 1.2 & 0.9 & 0.11 & 9.5 & -22.2 & 6.1 & 16.0 & 75.5 & 8.54 \\
\hline B55 & 39.293 & 120.891 & 0.7 & 0.5 & 0.06 & 9.7 & -22.0 & 5.7 & 13.7 & 59.8 & 26.6 \\
\hline B56 & 39.552 & 120.905 & 0.5 & 0.3 & 0.04 & 8.8 & -22.3 & 5.5 & 13.5 & 31.1 & 55.4 \\
\hline B65 & 37.919 & 119.322 & 0.6 & 0.6 & 0.08 & 8.8 & -24.0 & 5.5 & 42.3 & 57.2 & 0.48 \\
\hline B66 & 37.764 & 119.406 & 0.5 & 0.2 & 0.03 & 7.8 & -23.1 & 5.2 & 15.5 & 55.2 & 29.3 \\
\hline B67 & 37.752 & 119.583 & 0.7 & 0.6 & 0.08 & 8.8 & -22.6 & 6.2 & 24.8 & 71.4 & 3.78 \\
\hline B68 & 37.739 & 119.756 & 0.4 & 0.2 & 0.03 & 7.8 & -22.2 & 5.8 & 13.6 & 69.9 & 16.5 \\
\hline B69 & 37.728 & 119.942 & 0.6 & 0.4 & 0.05 & 9.3 & -22.3 & 5.4 & 17.9 & 71.8 & 10.3 \\
\hline B70 & 37.718 & 120.116 & 0.6 & 0.5 & 0.07 & 8.3 & -22.0 & 5.8 & 16.2 & 70.7 & 13.1 \\
\hline B71 & 38.009 & 120.327 & 0.4 & 0.2 & 0.03 & 7.8 & -21.9 & 5.3 & 10.3 & 64.9 & 24.8 \\
\hline $\mathrm{H} 1$ & 38.038 & 119.393 & 0.4 & 0.3 & 0.04 & 8.8 & -22.9 & 5.3 & 20.3 & 74.1 & 5.64 \\
\hline $\mathrm{H} 2$ & 38.097 & 119.173 & 0.4 & 0.4 & 0.06 & 7.8 & -22.7 & 6.4 & 23.5 & 61.2 & 15.3 \\
\hline $\mathrm{H} 3$ & 37.889 & 119.243 & 0.5 & 0.6 & 0.07 & 10.0 & -23.9 & 5.3 & 34.6 & 62.4 & 3.03 \\
\hline $\mathrm{H} 4$ & 37.874 & 119.393 & 0.3 & 0.3 & 0.03 & 11.7 & -23.4 & 5.1 & 13.1 & 63.1 & 23.8 \\
\hline H5 & 37.768 & 119.355 & 0.2 & 0.1 & 0.02 & 5.8 & -23.2 & 5.0 & 11.4 & 27.7 & 61.0 \\
\hline $\mathrm{H} 6$ & 37.757 & 119.441 & 0.2 & 0.2 & 0.04 & 5.8 & -23.0 & 5.1 & 13.9 & 68.4 & 17.7 \\
\hline $\mathrm{H} 7$ & 37.739 & 119.563 & 0.3 & 0.3 & 0.04 & 8.8 & -22.9 & 5.2 & 11.8 & 70.9 & 17.2 \\
\hline $\mathrm{H} 8$ & 38.001 & 119.203 & 0.5 & 0.4 & 0.06 & 7.8 & -22.7 & 5.2 & 22.9 & 64.1 & 13.1 \\
\hline H9 & 37.636 & 119.329 & 0.2 & 0.2 & 0.03 & 7.8 & -22.9 & 4.8 & 13.0 & 50.3 & 36.7 \\
\hline $\mathrm{H} 10$ & 37.629 & 119.420 & 0.3 & 0.3 & 0.04 & 8.8 & -22.8 & 5.4 & 16.4 & 68.6 & 15.0 \\
\hline $\mathrm{H} 11$ & 37.610 & 119.522 & 0.3 & 0.3 & 0.05 & 7.0 & -22.7 & 5.5 & 20.6 & 63.2 & 16.2 \\
\hline $\mathrm{H} 12$ & 37.555 & 119.148 & 0.1 & 0.2 & 0.02 & 11.7 & -22.9 & 5.2 & 5.70 & 64.8 & 29.5 \\
\hline $\mathrm{H} 13$ & 37.556 & 119.254 & 0.2 & 0.2 & 0.03 & 7.8 & -23.6 & 4.0 & 9.04 & 73.3 & 17.6 \\
\hline $\mathrm{H} 14$ & 37.535 & 119.378 & 0.3 & 0.4 & 0.05 & 9.3 & -22.8 & 4.7 & 19.9 & 68.9 & 11.2 \\
\hline H15 & 38.067 & 119.294 & 0.5 & 0.5 & 0.07 & 8.3 & -22.4 & 5.4 & 25.0 & 69.9 & 5.15 \\
\hline $\mathrm{H} 16$ & 37.500 & 119.055 & 0.3 & 0.2 & 0.03 & 7.8 & -22.6 & 5.4 & 12.2 & 71.6 & 16.1 \\
\hline $\mathrm{H} 17$ & 37.492 & 119.134 & 0.3 & 0.3 & 0.04 & 8.8 & -22.8 & 5.3 & 14.6 & 68.8 & 16.6 \\
\hline $\mathrm{H} 18$ & 37.485 & 119.314 & 0.3 & 0.4 & 0.05 & 9.3 & -23.0 & 5.0 & 33.3 & 65.0 & 1.66 \\
\hline L1 & 37.778 & 119.379 & 0.4 & 0.2 & 0.02 & 11.7 & -23.6 & 5.2 & 11.2 & 49.2 & 39.6 \\
\hline L2 & 37.755 & 119.607 & 0.9 & 0.4 & 0.06 & 7.8 & -22.4 & 5.9 & 26.5 & 68.2 & 5.29 \\
\hline L3 & 37.724 & 119.860 & 1.0 & 0.6 & 0.08 & 8.8 & -22.2 & 5.7 & 26.7 & 66.9 & 6.43 \\
\hline L4 & 37.696 & 120.088 & 0.7 & 0.4 & 0.05 & 9.3 & -22.1 & 5.6 & 22.3 & 62.1 & 15.5 \\
\hline L5 & 37.639 & 120.268 & 0.4 & 0.1 & 0.02 & 5.8 & -21.8 & 6.1 & 20.2 & 42.5 & 37.2 \\
\hline L6 & 37.636 & 119.342 & 0.4 & 0.2 & 0.03 & 7.8 & -23.1 & 4.5 & 17.2 & 70.1 & 12.7 \\
\hline L7 & 37.619 & 119.533 & 0.5 & 0.3 & 0.05 & 7.0 & -22.7 & 5.5 & 20.0 & 61.8 & 18.2 \\
\hline L8 & 37.585 & 119.781 & 0.4 & 0.2 & 0.03 & 7.8 & -22.1 & 5.0 & 11.6 & 50.5 & 37.9 \\
\hline L9 & 37.559 & 120.007 & 0.5 & 0.1 & 0.02 & 5.8 & -21.5 & 5.5 & 11.3 & 48.6 & 40.1 \\
\hline L10 & 37.553 & 120.199 & 0.5 & 0.2 & 0.03 & 7.8 & -21.4 & 4.9 & 10.9 & 55.6 & 33.5 \\
\hline L11 & 37.499 & 119.872 & 0.4 & 0.1 & 0.02 & 5.8 & -21.4 & 5.7 & 5.07 & 48.3 & 46.6 \\
\hline L12 & 37.505 & 119.627 & 0.4 & 0.2 & 0.04 & 5.8 & -22.5 & 6.4 & 11.4 & 46.5 & 42.2 \\
\hline L13 & 37.524 & 119.139 & 0.4 & 0.2 & 0.03 & 7.8 & -22.7 & 4.8 & 12.3 & 67.4 & 20.3 \\
\hline L14 & 37.529 & 119.233 & 0.4 & 0.1 & 0.02 & 5.8 & -22.8 & 5.1 & 8.22 & 55.8 & 36.0 \\
\hline L15 & 37.496 & 119.405 & 0.6 & 0.4 & 0.06 & 7.8 & -23.0 & 5.5 & 25.3 & 66.4 & 8.35 \\
\hline L16 & 37.403 & 119.589 & 0.3 & 0.1 & 0.02 & 5.8 & -22.0 & 5.6 & 6.22 & 49.1 & 44.7 \\
\hline L17 & 37.335 & 119.731 & 0.4 & 0.2 & 0.03 & 7.8 & -22.0 & 6.2 & 13.7 & 51.3 & 35.0 \\
\hline L18 & 37.269 & 119.853 & 0.4 & 0.3 & 0.03 & 11.7 & -22.0 & 6.4 & 6.42 & 37.0 & 56.6 \\
\hline L19 & 37.500 & 119.021 & 0.5 & 0.2 & 0.03 & 7.8 & -22.7 & 5.6 & 13.73 & 58.7 & 27.5 \\
\hline L20 & 37.454 & 119.125 & 0.6 & 0.4 & 0.06 & 7.8 & -22.9 & 6.2 & 21.8 & 72.8 & 5.43 \\
\hline L21 & 37.370 & 119.301 & 0.6 & 0.4 & 0.06 & 7.8 & -22.8 & 6.2 & 22.6 & 71.7 & 5.68 \\
\hline L22 & 37.286 & 119.489 & 0.2 & 0.1 & 0.02 & 5.8 & -21.8 & 6.1 & 2.98 & 48.5 & 48.6 \\
\hline L23 & 37.240 & 119.607 & 0.2 & 0.1 & 0.02 & 5.8 & -21.5 & 7.4 & 2.76 & 46.0 & 51.2 \\
\hline L24 & 37.188 & 119.744 & 0.2 & 0.1 & 0.01 & 11.7 & -21.9 & 5.2 & 0.00 & 26.6 & 73.4 \\
\hline L25 & 37.369 & 119.062 & 0.3 & 0.1 & 0.02 & 5.8 & -22.6 & 6.4 & 6.39 & 47.2 & 46.4 \\
\hline L26 & 37.310 & 119.173 & 0.5 & 0.3 & 0.04 & 8.8 & -22.6 & 6.7 & 15.5 & 62.9 & 21.6 \\
\hline L27 & 37.211 & 119.369 & 0.2 & 0.1 & 0.01 & 11.7 & -20.8 & 7.3 & 1.77 & 29.1 & 69.1 \\
\hline
\end{tabular}



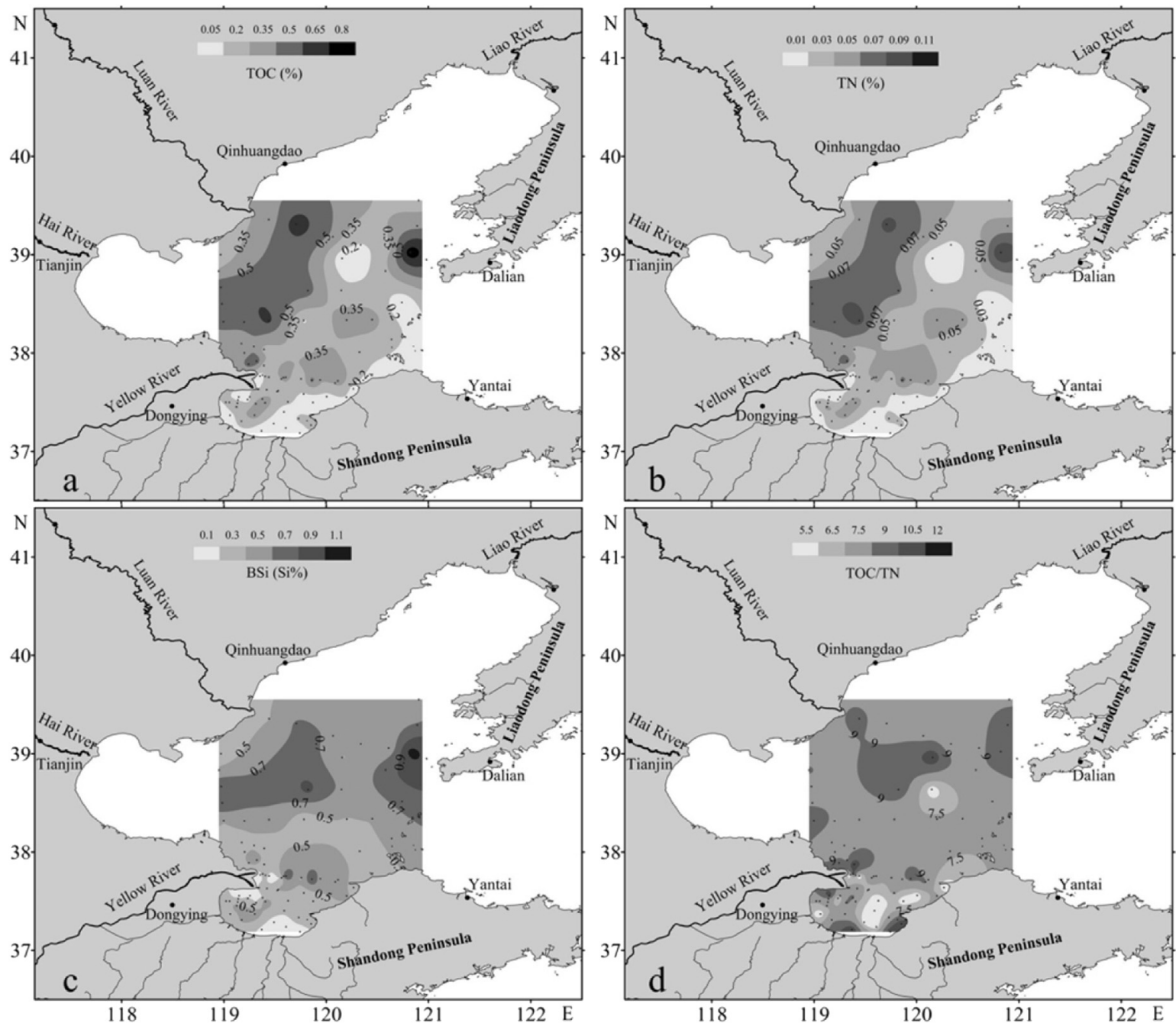

Fig. 3. Spatial distribution of TOC (a), TN (b), and BSi (c) concentrations and TOC/TN ratio (d) in surface sediments of the study area.

dominant nitrogen sources. In this paper, we map the spatial distribution of organic carbon, total nitrogen and biogenic silica (BSi) in the YR mouth and adjacent sea, elucidate the carbon and nitrogen sources based on their isotopic composition and use a simple end-member mixing model to assess the relative contributions of marine and terrestrial organic matter.

\section{Materials and methods}

\subsection{Study area and sampling methods}

The BS is a shallow, semi-enclosed inland sea with surface area of $7.7 \times 10^{4} \mathrm{~km}^{2}$ and an average depth of $18 \mathrm{~m}$ (Fig. 1). The LB (with an area of approximately $7000 \mathrm{~km}^{2}$ and water depths in most areas that are less than $10 \mathrm{~m}$ ) is located in the southern BS and receives input from the YR (Fig. 1). Aside from the YR, more than 10 continental rivers (e.g., the Xiaoqing, Bailang, Guangli, Wei, and Jiaolai Rivers) discharge into the LB, and they bring abundant nutrients into the bay that supports high primary productivity.

The circulation in BS is mainly driven by tidal currents, and intrusions of Yellow Sea waters and YR discharge also play important roles in the thermohaline circulation and sedimentary environment (Guan, 1994; Su, 1998). In winter, the Yellow Sea Warm Current (YSWC) intrudes and crosses the Bohai Strait, typically moving

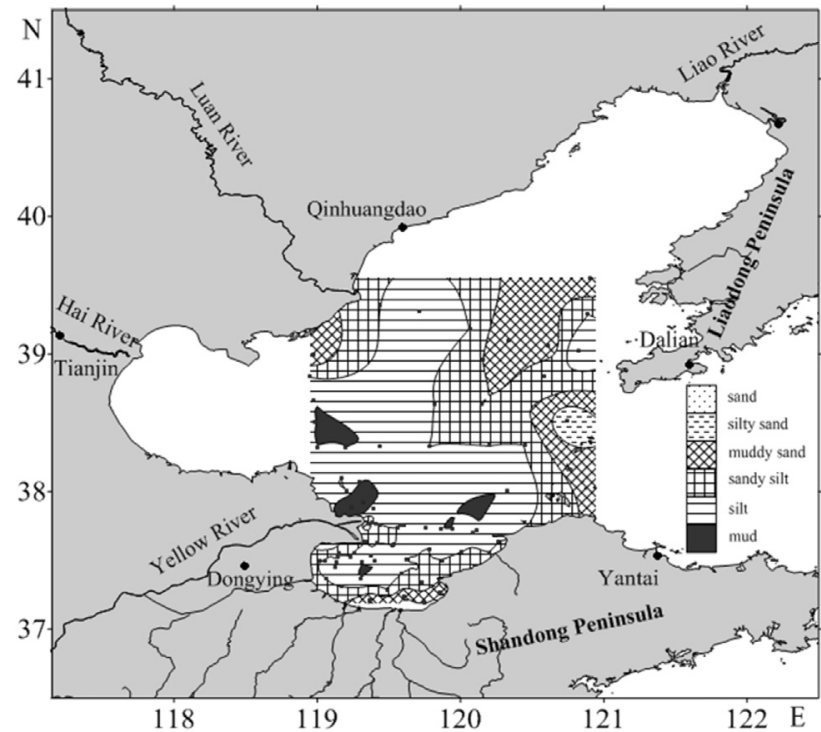

Fig. 4. Spatial distribution of sediment grain sizes of the study area. 

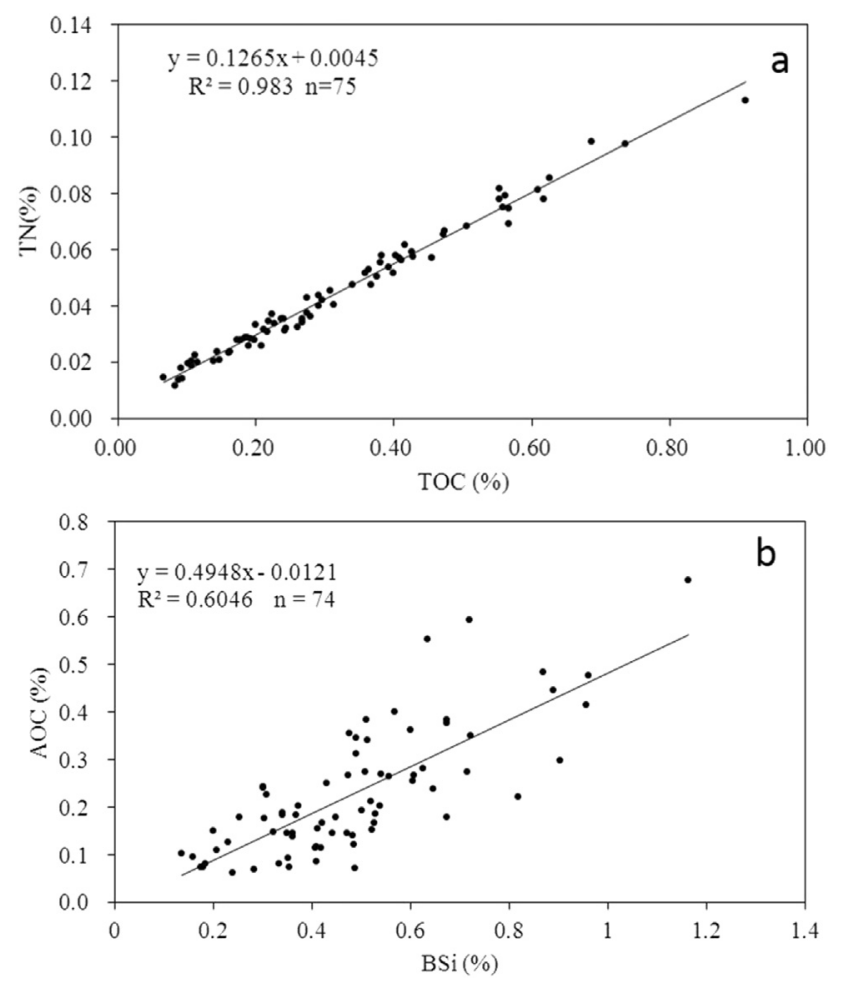

Fig. 5. Linear correlations between $\mathrm{TOC}$ and $\mathrm{TN}$ (a) and between $\mathrm{AOC}$ and BSi (b).

westward along the central part of the sea and then splitting into two branches. The first moves toward the northeast to form a clockwise gyre, and the second veers southward and then turns eastward along the southern coast to form a counter clockwise gyre (Fig. 2a). The YSWC disappears in summer, and eddies generated in the BS are more pronounced than in winter. Whereas the central eddy disappears in summer, the eddy in the LB is pronounced, and a coastal current along the southern and western coastlines of the BS is established (Fig. 2b) (Hainbucher et al., 2004).

The sample pool covers a region near the YR mouth, the LB and the Central BS (Fig. 1b), and includes thirty-one sites in the Central BS (Fig. 1b) and thirty-three sites in the YR mouth and the LB (Fig. 1c). Surface sediments were collected with a box corer $\left(0.1 \mathrm{~m}^{2}\right)$ at each site during two summer cruises in 2011. The top $2 \mathrm{~cm}$ were sampled and kept in a freezer on the ship, and then were transported back to the laboratory for analysis.

\subsection{Analysis of sediment grain size}

The grain size of sediments was analysed by a Mastersize 2000 Laser Particle Sizer in the laboratory. The sediment samples were first oxidized by $10 \% \mathrm{H}_{2} \mathrm{O}_{2}$ to remove organic matter, and then dispersed in a $0.05 \%\left(\mathrm{NaPO}_{3}\right)_{6}$ solution to disaggregate particles. Grain sizes were classified into clay $(<4 \mu \mathrm{m})$, silt $(4-63 \mu \mathrm{m})$ and sand $(>63 \mu \mathrm{m})$ according to standard nomenclature (Folk et al., 1970).

\subsection{Analysis of organic carbon and nitrogen}

Freeze-dried sediment samples were homogenized by grinding, and then the weighed aliquots were acidified by adding $2 \mathrm{~mL}$ of $1 \mathrm{M}$ $\mathrm{HCl}$ to every $100 \mathrm{mg}$ of sample. The acidified samples were dried at $>60{ }^{\circ} \mathrm{C}$ under a stream of filtered air, then mixed with $1 \mathrm{~mL}$ Milli-Q water and freeze-dried again. Samples were weighed again to account for the change of weight during the acid treatment. Aliquots of approximately $20 \mathrm{mg}$ were weighed into $5 \times 8 \mathrm{~mm}$ tin capsules for the measurement of total organic carbon (TOC), total nitrogen (TN), and carbon and nitrogen isotopes $\left(\delta^{13} \mathrm{C}\right.$ and $\left.\delta^{15} \mathrm{~N}\right)$ using a continuous-flow isotope-ratio mass spectrometer (Delta V Advantage, Thermo Scientific, Germany) coupled to an elemental analyser (Flash EA 1112 Thermo Scientific, Italy) in the laboratory of Littoral Environment et Sociétés (LIENSs)-UMR7266, France. The results are expressed relative to Vienna PeeDee Belemnite and atmospheric $\mathrm{N}_{2}$ for $\delta^{13} \mathrm{C}$ and $\delta^{15} \mathrm{~N}$, respectively. Replicates of an acetanilide standard (Thermo Scientific) were analysed along with samples, and indicated that the analytical errors were $<0.1 \%$ for both $\delta^{13} \mathrm{C}$ and $\delta^{15} \mathrm{~N}$. The $\mathrm{C} / \mathrm{N}$ ratios were determined as $\mathrm{mol} / \mathrm{mol}$ ratios, which transformed from the \%TOC and \%TN weight data obtained as part of the stable isotope analyses. Replicate measurements of a certified reference material (Low Organic Content Soil, Elemental MicroAnalysis, UK) indicated analytical errors of $0.025 \%$ and $0.002 \%$ for $\%$ TOC and \%TN, respectively.

The acid treatment of samples prior to analysis may alter the $\delta^{15} \mathrm{~N}$ values, but based on two lines of evidence we think that the effect is limited. The shift incurred from acid treatment is highly variable depending on the carbonate content (and the amount of $\mathrm{HC}$ added), the granulometry of the sample, and the quality of the organic matter. When processing samples, we analysed a few random samples in the laboratory in France to constrain the shift from untreated to acid-treated samples, and found that $\delta^{15} \mathrm{~N}$ values of acidified samples were around $0.2 \%$ higher than those of nonacidified samples. Second, 11 sub-samples of the sample set described here were also analysed in a laboratory in Germany, where no acid pre-treatment prior to $\delta^{15} \mathrm{~N}$ determination is performed. In this informal comparison between treatments and laboratories we found that $\delta^{15} \mathrm{~N}$ values of acid treated samples were systematically higher by $0.5 \%$ at total carbon (TC) concentrations of the samples $<1.5$ weight\%. At higher TC concentrations, the difference varied unsystematically and differences were larger. This is very likely an effect of the amount of acid needed to remove inorganic carbon (TIC), which in the sample set analysed in both laboratories averages 0.76 weight\% (TIC range $0.11-1.55$ weight \%, or $\left.1-13 \% \mathrm{CaCO}_{3}\right)$. The mean TC concentration of the entire sample set analysed in Germany from the Bohai Sea is 1.2 weight \%. We chose to use the larger data set based on acidified samples as the basis for this paper, and alert the reader to the possible bias.

\subsection{Analysis of biogenic silica (BSi)}

Three replicates of each sediment sample were analysed using the wet alkaline leaching method (DeMaster, 1981; Kamatani and Oku, 2000). The sediment samples were freeze-dried and

Table 2

Comparison of organic matters in the surface sediments from large river mouths and Bohai Sea.

\begin{tabular}{|c|c|c|c|c|c|c|}
\hline Location & TOC $(\%)$ & $\mathrm{TN}(\%)$ & $\delta^{13} \mathrm{C}(\% 0)$ & $\delta^{15} \mathrm{~N}(\% 0)$ & $\mathrm{C}: \mathrm{N}$ & Reference \\
\hline Pearl River Estuary and adjacent shelf, China & $0.06-1.02$ & $0.03-0.19$ & -24.6 to -22.1 & $3.9-6.4$ & $1.8-9.1$ & Hu et al., 2006 \\
\hline Changjiang Estuary and adjacent shelf, China & $0.17-0.82$ & - & -24.5 to -21.2 & $3-8.0$ & 4.98to 13.44 & Zhang et al., 2007; Hu et al., 2012 \\
\hline Ayeyarwady Estuary and adjacent shelf, India & $0.07-1.4$ & $0.01-0.24$ & -25.9 to -20.5 & $3.2-6.6$ & $4.5-10.0$ & Ramaswamy et al., 2008 \\
\hline Yellow River Estuary and adjacent shelf, China & $0.08-0.91$ & $0.01-0.11$ & -23.9 to -20.8 & $4.01-7.28$ & $5.8-11.7$ & This study \\
\hline Bohai Sea, China & $0.04-0.69$ & $0.01-0.1$ & -24.0 to -21.7 & - & $5-11$ & Hu et al., 2009 \\
\hline
\end{tabular}



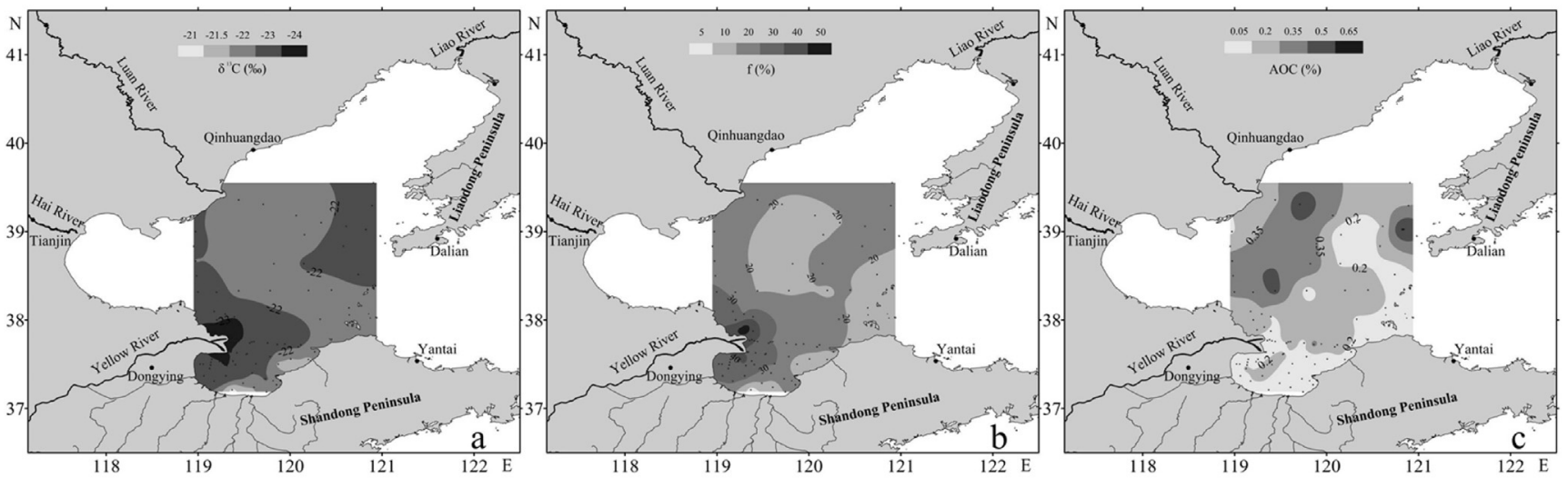

Fig. 6. Spatial distributions of $\delta^{13} \mathrm{C}(\mathrm{a}), f(\mathrm{~b})$ and $\mathrm{AOC}$ (c) of the study area.

homogenized, and a subsample of $0.15 \mathrm{~g}$ of each sediment sample was weighed into a $100 \mathrm{~mL}$ polypropylene centrifuge tube. First, $10 \mathrm{~mL}$ of $10 \% \mathrm{H}_{2} \mathrm{O}_{2}$ and $10 \% \mathrm{HCl}$ were added to the samples to remove organic matter and carbonate, respectively, and then the extra hydrochloric acid and peroxide were washed out using Milli$Q$ water. The wet samples were placed in an oven to dry over night at $60{ }^{\circ} \mathrm{C}$, and then were extracted with $2 \mathrm{M} \mathrm{Na}_{2} \mathrm{CO}_{3}$ at $85^{\circ} \mathrm{C}$ for an 8 $\mathrm{h}$ digestion. It is necessary to gently swirl the samples for homogenization during the digestion processes. At 1-h intervals, $0.1 \mathrm{~mL}$ of alkaline solution was extracted for measurement by the molybdate blue spectrophotometric method using OUXI TU-1810.

\section{Results and discussion}

\subsection{Spatial distribution of TOC, TN, BSi and $C / N$}

TOC and TN contents range from 0.08 to $0.9 \%$ and $0.01-0.11 \%$ (Table 1 ). High values (TOC $>0.5 \%$; TN $>0.07 \%$ ) mainly occur in the west of the Central BS and in a small region near the Liaodong peninsula, and low values (TOC $<0.2 \%$; TN $<0.03 \%$ ) dominate in the Bohai Strait and in a small middle region in the Central BS (Fig. 3a, b).

The spatial distribution of TOC and TN in the study area mirrors

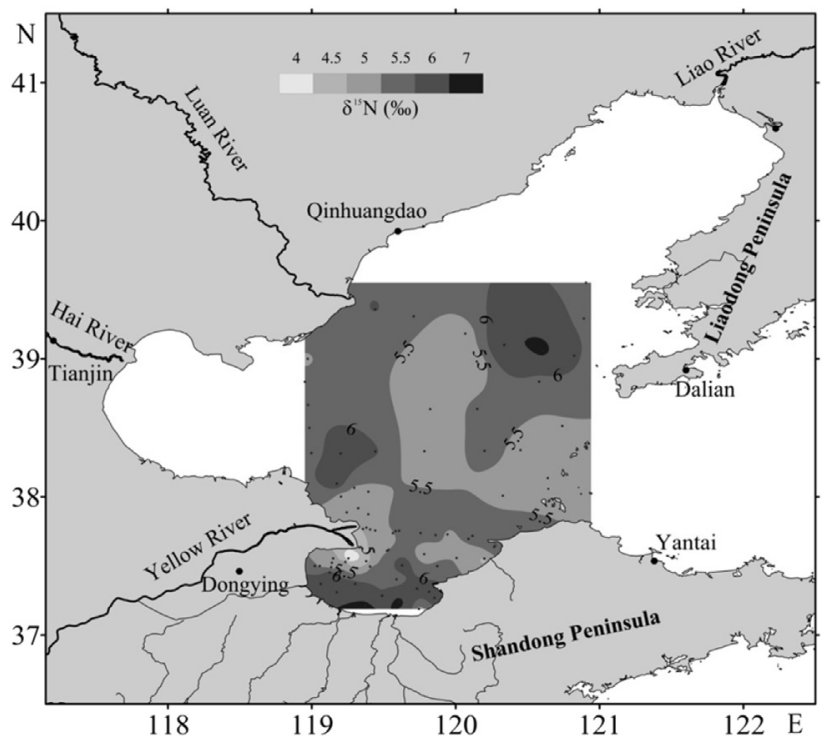

Fig. 7. Spatial distribution of $\delta^{15} \mathrm{~N}$ in surface sediments of the study area. variable dilution with detrital material. Due to the high suspended matter discharge of the YR, the sediment deposition rates in the BS are variable and range from 1 to $9 \mathrm{~cm} \mathrm{a}^{-1}$ in the YR mouth and the LB to $0.1-0.4 \mathrm{~cm} \mathrm{a}^{-1}$ in the Central BS and the Bohai Strait (Ren and Shi, 1986; Zhu and Chang, 2000; Li et al., 2002). High deposition rates of detrital material dilute the OM from primary production, so that the bulk of organic carbon and total nitrogen in the sediment near the discharge area is associated with the river suspended load. Moreover, primary production is limited by high turbidity in the river plume, and results in low phytoplankton-derived organic carbon deposition rates. This phenomenon is observed in other large rivers with high suspended matter loads, e.g., the Yangtze, Pearl and Ayeyarwady Rivers (Zhang et al., 1990; Hu et al., 2006; Ramaswamy et al., 2008).

Sediment grain size is indicative of kinetic energy at the sea floor, and also determines whether diffusive or advective processes act on the preservation of OM during early diagenesis. Generally, fine-grained sediments have higher \%TOC than coarse sediments (Canfield, 1994), and the fine-grained sediments (mud and silt) dominating in the Central BS are associated with higher OM contents, whereas coarse-grained sediments (silty sand and sand) in the Bohai Strait have the lowest OM concentrations (Fig. 4). The speed of bottom currents in the Bohai Strait $\left(1.5-2.0 \mathrm{~m} \mathrm{~s}^{-1}\right)$ is much faster than in the Central BS $\left(0.5-1.0 \mathrm{~m} \mathrm{~s}^{-1}\right)$ and the $\mathrm{LB}\left(0.5 \mathrm{~m} \mathrm{~s}^{-1}\right)$ (Qiao et al., 2010). This is reflected in coarse-grained sediments in the Bohai Strait and implies selective winnowing and removal of OM from the sediment.

$\mathrm{BSi}$ in the surface sediment reflects the contribution of siliceous phytoplankton (e.g., diatoms, silicoflagellates) that are the main primary producers in many coastal seas (DeMaster, 2002; Bernárdez et al., 2005; Krause et al., 2011). BSi concentrations at the sampling sites ranged from $0.1 \%$ to $1.1 \%$ (Table 1 ), and two areas with the highest values (BSi > 0.7\%) (Fig. 3c) coincide with maximum TOC and TN areas in the Central BS (Fig. 3a, b), suggesting significant OM contributions from marine production.

$\mathrm{C}: \mathrm{N}$ ratios can be a potential indicator for elucidating marine and terrestrial organic matter (5-7 for marine-derived OM by Redfield et al., 1963; >12 for terrestrial-derived OM by Meyers, 1997). However, mineralization, oxidation and significant fractions of inorganic nitrogen impact C:N ratios and limit their usefulness as source indicators (Andrews et al., 1998; Kuwae et al., 2006). In this study, a significant linear correlation between TOC and TN indicated that $\mathrm{N}$ is predominantly bound to OM (Fig. 5a). C:N ratios varied from 5.8 to 11.7 (Table 1 ), indicating a mixture of marine and terrestrial sources. In comparison, higher values basically occurred nearby the rive plume to the BS (YR, Luan River, and Fuzhou River near Liaodong peninsula), suggesting the impact of 
Table 3

Catchment information of main rivers in the southern coast of Laizhou Bay.

\begin{tabular}{|c|c|c|c|c|c|c|}
\hline Rivers & Stem length (km) & Catchment size $\left(\mathrm{km}^{2}\right)$ & Population & Livestock (number) & Agricultural area $\left(\mathrm{km}^{2}\right)$ & Aquatic farming area $\left(\mathrm{km}^{2}\right)$ \\
\hline Xiaoqing River & $2.4 \times 10^{2}$ & $1.0 \times 10^{4}$ & $5.6 \times 10^{6}$ & $1.7 \times 10^{6}$ & $4.1 \times 10^{3}$ & 170 \\
\hline Mi River & $2.1 \times 10^{2}$ & $3.8 \times 10^{3}$ & $2.8 \times 10^{6}$ & $5.2 \times 10^{5}$ & $2.0 \times 10^{3}$ & 78 \\
\hline Bailang River & $1.3 \times 10^{2}$ & $1.2 \times 10^{3}$ & $1.2 \times 10^{6}$ & $1.1 \times 10^{5}$ & $7.1 \times 10^{2}$ & 22 \\
\hline Wei River & $2.5 \times 10^{2}$ & $6.4 \times 10^{3}$ & $7.0 \times 10^{6}$ & $2.2 \times 10^{6}$ & $5.2 \times 10^{3}$ & 260 \\
\hline Jiaolai River & $1.3 \times 10^{2}$ & $5.5 \times 10^{3}$ & $3.4 \times 10^{6}$ & $1.2 \times 10^{6}$ & $3.7 \times 10^{3}$ & 140 \\
\hline
\end{tabular}

Data source: Statistical Yearbook 2010 of Shandong province.

land-derived inputs (Fig. 3d). Some low C:N ratios prevailed in the LB (Fig. 3d). Marine sediments with C:N lower than the Redfield Ratio were reported in some N-rich coastal environments, due to excessive supply of inorganic nitrogen from anthropogenic sources (Tyson, 1995; Ruttenberg and Goñi, 1997; Ramaswamy et al., 2008). This was explained in Section 3.3 combining with the result of $\delta^{15} \mathrm{~N}$.

\subsection{Spatial distribution of $\delta^{13} \mathrm{C}$}

The $\delta^{13} \mathrm{C}$ values range from $-20.8 \%$ to $-23.9 \%$ (Table 1 ) and indicate a mixture of organic carbon of marine and terrestrial sources (Pancost and Boot, 2004) which was consistent with previous results in large river mouth and BS (Table 2). The trend toward higher values in the offshore direction reflects a relative increase in the contribution of marine-derived organic carbon ( $-19 \%$ to $-21 \%$ for typical marine-derived organic carbon by Fry and Sherr, 1984) over the river-derived terrigenous fraction $\left(\delta^{13} \mathrm{C}\right.$ of $-27.0 \%$ ) (Fig. 6a). As expected, the lowest $\delta^{13} \mathrm{C}$ values $(<-23 \%$ ) occur at the YR mouth, and the spatial distribution of low $\delta^{13} \mathrm{C}$ values tracks the dispersal of YR-derived sediments in the YR mouth and the LB (Fig. 6a). Previous studies of transport of YR sediment in the BS showed that river suspensions rapidly settle out of the river plume and that approximately $90 \%$ of the sediment load is deposited within $30 \mathrm{~km}$ of the YR mouth, whereas the YR plume flows northeastward into the LB and the Central BS and can even reach the Bohai Strait (Bornhold et al., 1986). Zhang et al. (1990) estimated that only $5-10 \%$ of YR-derived sediments reach the central BS and/or the Bohai Strait.

We estimated the relative proportions of terrestrial and marine organic carbon present in the sediments with the end-member mixing model of Shultz \& Calder (1976), which assumes discrete $\delta^{13} \mathrm{C}$ values for terrestrial and marine end-member carbon. We assumed that the $\delta^{13} \mathrm{C}$ of terrestrial carbon is $-27.0 \%$, which is close to the $\mathrm{C}_{3}$ plants that dominate in northern China (Guo et al., 2006). A $\delta^{13} \mathrm{C}$ of $-20.3 \%$ was chosen as the marine end-member based on the $\delta^{13} \mathrm{C}$ of BS phytoplankton (Wan et al., 2005). The relative contribution of the terrestrial-derived organic carbon $(f \%)$ was calculated as (Minoura et al., 1997; Hu et al., 2006):

$f(\%)=\frac{\delta^{13} C_{\text {marine }}-\delta^{13} C_{\text {sediment }}}{\delta^{13} C_{\text {marine }}-\delta^{13} C_{\text {terrestrial }}} \times 100$

The contribution of marine algae $\left(f^{\prime}\right)$ to TOC was obtained from:

$f^{\prime}=1-f$

The content of algal-derived organic carbon (AOC) was calculated as:

$\mathrm{AOC}=\mathrm{TOC} \times f^{\prime}$

The highest $f$ values (40-50\%) reveal the YR mouth (Fig. 6b) as the area with the highest terrestrial organic carbon contribution from the YR to the adjacent sea. In the Central BS, approximately $10-20 \%$ of the organic carbon is terrigenous, and the terrigenous carbon percentage diminishes to approximately $10 \%$ in the Bohai
Strait (Fig. 5b). Accordingly, AOC values are highest in the Central BS (Fig. 6c) and correlate significantly with peak BSi and TOC concentrations (Fig. 5b).

\subsection{Spatial distribution of $\delta^{15} N$}

The $\delta^{15} \mathrm{~N}$ of surface sediments reflects the dominant source of reactive nitrogen, but is biased by diagenetic processes. Over the study area, most $\delta^{15} \mathrm{~N}$ values at sampling sites range from 5 to $6 \%$ (Table 1), which is a typical range of marine organic matter produced from assimilation of the marine nitrate pool (Thornton and McManus, 1994; Brandes and Devol, 2002). The lowest $\delta^{15} \mathrm{~N}$ values occur in the YR mouth (4-5\%; Fig. 7) and are similar to the range found in other high turbidity river discharge systems (Table 2), reflecting the dominant contribution of river suspended load to sediment organic matter. River suspended matter is quite variable, but has generally lower $\delta^{15} \mathrm{~N}$ values than sinking organic matter in the sea, due to the contributions of terrestrial plant and soil nitrogen (Altabet, 1996). The $\delta^{15} \mathrm{~N}$ values of suspended matter in the YR were reported to range from +3.2 to $+4.5 \%$ (Zhang et al., 2012), in line with our data. A second process that enhances the gradient is incomplete utilization of nitrate and the associated $\delta^{15} \mathrm{~N}$ enrichment of residual nitrate in the river plume caused by light limitation in turbid waters.

In contrast, the highest $\delta^{15} \mathrm{~N}$ values (6-7.4\%) were observed in the southern coast of the LB (Fig. 7). There are more than 10 continental rivers discharging into the southern coast of the LB, and watersheds receive the nitrogen from fertilizer and manure used on farmlands, urban sewage input and aquaculture (Table 3). In general, nitrate delivered from farm runoff and human sewage has elevated $\delta^{15} \mathrm{~N}$ values between 10-25\% (Heaton, 1986; Kendall, 1998). In Baltic rivers, Voss et al. (2006) estimated that $\delta^{15} \mathrm{~N}-\mathrm{NO}_{3}$ of $6-8 \%$ indicate that farmland and/or waste water effluents contribute $60-70 \%$ of nitrate. In Cape Cod, $\delta^{15} \mathrm{~N}$ values in ground water impacted by waste water input were generally in a range of $6-8 \%$ (Cole et al., 2006). Unfortunately, we did not find values of $\delta^{15} \mathrm{~N}$ for rivers near the LB recorded in the literature. The maximum $\delta^{15} \mathrm{~N}$ in Pearl and Changjiang estuaries might help to indicate a status of nitrogen pollution in coastal waters of China (Table 2). Monitoring data (Bulletin of China Ocean Environmental State, 2009-2014) also suggested the impact of anthropogenic nitrogen input, and classified the southern coast of the LB as a heavily polluted area, which means that DIN concentrations of sea water reach the national standard of nitrogen pollution $(>28 \mu \mathrm{M})$. Some in situ surveys even found that DIN concentrations in summer can reach to 38.6-70 $\mu \mathrm{M}$ (Xia et al., 2009; Su et al., 2015). This information not only explained why the lowest $\mathrm{C}: \mathrm{N}$ ratios (Fig. 3d) occurred in the southern area of the LB but also indicated a significant sink of anthropogenic nitrogen brought by river input.

\section{Conclusions}

The patterns of TOC and TN concentrations and of $\delta^{13} \mathrm{C}$ and $\delta^{15} \mathrm{~N}$ in sediments trace the sources of OM in the Bohai Sea. There is a 
general gradient of decreasing terrigenous OM away from the Yellow River mouth and from the coast to open marine areas, and a concomitant increase in the relative contribution of OM from marine productivity. The sediment texture, marine primary production, fluvial OM deposition rate and current speed jointly determine the spatial patterns. In the YR mouth, the terrigenous $\mathrm{OM}$ is rapidly deposited and buried near the delta, and approximately contributes $40-50 \%$ to total OM in sediments. In the Central BS and Bohai Strait, marine-derived organic carbon (AOC) dominates in sediments, whereas the terrigenous OM only contributes $10-20 \%$. The highest $\delta^{15} \mathrm{~N}$ values near the southern coast of the LB indicate a significant input of ${ }^{15} \mathrm{~N}$-enriched riverine nitrogen linked with anthropogenic activity in the catchments of medium and small rivers that discharge into this bay.

\section{Acknowledgements}

This work was sponsored by the Natural Science Foundation of China (41376121), the Strategic Priority Research Program of the Chinese Academy of Sciences (XDA11020405) and the Natural Science Foundation of Shandong Province (JQ201414). We acknowledge the helpful suggestions of two anonymous reviewers and by the associate editor on a previous version of the manuscript.

\section{References}

Andrews, J.E., Greenaway, A.M., Dennis, P.F., 1998. Combined carbon isotope and C/N ratios as indicators of source and fate of organic matter in a poorly flushed, tropical estuary: Hunts Bay, Kingston Harbour, Jamaica. Estuar. Coast. Shelf Sci. 46, 743-756.

Altabet, M., 1996. Nitrogen and Carbon Isotopic Tracers of the Source and Transformation of Particles in the Deep Sea. In: Ittekkot, V., Schaefer, P., Honjo, S. Depetris, P.J. (Eds.), Particle Flux in the Ocean, SCOPE, vol. 57. Wiley \& Sons, Chichester, pp. 155-184.

Bernárdez, P., Prego, R., Frances, G., Gonzalez-Alvarez, R., 2005. Opal content in the Ria de Vigo and Galician continental shelf: biogenic silica in the muddy fraction as an accurate paleoproductivity proxy. Cont. Shelf Res. 25, 1249-1264.

Bornhold, B.D., Yang, Z.S., Keller, G.H., Prior, D.B., Wiseman Jr., W.J., Wang, Q., Wright, L.D., Xu, W.D., Zhuang, Z.Y., 1986. Sedimentary framework of the Modern Huanghe (Yellow River) Delta. Geo Mar. Lett. 6, 77-83.

Brandes, J.A., Devol, A.H., 2002. A global marine-fixed nitrogen isotopic budget: implications for Holocene nitrogen cycling. Glob. Biogeochem. Cycles 16, 67$1-67-14$.

Bulletin of China Ocean Environmental State, 2009-2014. Press in State Oceanic Administration People's Republic of China. Beijing (in Chinese).

Canfield, D.E., 1994. Factors influencing organic carbon preservation in marine sediments. Chem. Geol. 114, 315-329.

Cole, M.L., Kroeger, K.D., McClelland, J.W., Valiela, I., 2006. Effects of watershed land use on nitrogen concentrations and $\delta^{15}$ nitrogen in groundwater. Biogeochemistry $77,199-215$.

DeMaster, D.J., 1981. The supply and accumulation of silica in the marine environment. Geochim. Cosmochim. Acta 45, 1715-1732.

DeMaster, D.J., 2002. The accumulation and cycling of biogenic silica in the Southern Ocean: revisiting the marine silica budget. Deep Sea Res. Part II 49, 3155-3167.

Folk, R.L., Andrews, P.B., Lewis, D.W., 1970. Detrital sedimentary rock classification and nomenclature for us in New Zealand. N. Z. J. Geol. Geophys. 13, 937-968.

Fry, B., Sherr, E.B., 1984. $\delta^{13} \mathrm{C}$ measurements as indicators of carbon flow in marine and freshwater ecosystems. Mar. Sci. 27, 13-47.

Guan, B.X., 1994. Patterns and structures of the currents in Bohai, Huanghai and East China Sea. In: Zhou, D., Liang, Y.B., Tseng, C.K. (Eds.), Oceanology of China Sea. Kluwer Academic Publishers, The Netherlands, pp. 17-26.

Guo, Z.G., Li, J.Y., Feng, J.L., Fang, M., Yang, Z.S., 2006. Compound-specific carbon isotope compositions of individual long-chain n-alkanes in severe Asian dust episodes in the North China coast in 2002. Chin. Sci. Bull. 51, 2133-2140.

Hainbucher, D., Wei, H., Pohlmann, T., Sündermann, J., Feng, S., 2004. Variability of the Bohai Sea circulation based on model calculations. J. Mar. Syst. 44, 153-174.

Heaton, T.H.E., 1986. Isotopic studies of nitrogen pollution in the hydrosphere and atmosphere: a review. Chem. Geol. 59, 87-102.

Hedges, J.I., Keil, R.G., Benner, R., 1997. What happens to terrestrial organic matter in the ocean? Org. Geochem. 27, 195-212.

Hu, B., Li, J., Bi, N., Wang, H., Wei, H., Zhao, J., Xie, L., Zou, L., Cui, R., Li, S., Liu, M., Li, G., 2015. Effect of human-controlled hydrological regime on the source, transport, and flux of particulate organic carbon from the lower Huanghe (Yellow River). Earth Surf. Process Landf. http://dx.doi.org/10.1002/esp.3702.

Hu, J.F., Peng, P.A., Jia, G.D., Mai, B.X., Zhang, G., 2006. Distribution and sources of organic carbon, nitrogen and their isotopes in sediments of the subtropical
Pearl River Estuary and adjacent shelf, Southern China. Mar. Chem. 98, $274-285$.

Hu, L., Guo, Z., Feng, J., Yang, Z., Fang, M., 2009. Distributions and sources of bulk organic matter and aliphatic hydrocarbons in surface of the Bohai Sea, China. Mar. Chem. 113, 197-211.

Hu, L., Shi, X., Yu, Z., Lin, T., Wang, H., Ma, D., Guo, Z., Yang, Z., 2012. Distribution of sedimentary organic matter in estuarine-inner shelf regions of the East China Sea: implications for hydrodynamic forces and anthropogenic impact. Mar. Chem 142, 29-40.

Kamatani, A., Oku, O., 2000. Measuring biogenic silica in marine sediments. Mar. Chem. 68, 219-229.

Kendall, C., 1998. Tracing nitrogen sources and cycling in catchments. In: Kendall, C., McDonnell, J.J. (Eds.), Isotope Tracers in Catchment Hydrology. Elsevier, Amsterdam, pp. 519-576.

Kuwae, M., Yamaguchi, H., Tsugeki, N.T., Miyasaka, H., Fukumori, K., Ikehara, M., Genkai-Kato, M., Omori, K., Sugimoto, T., Ishida, S., Takeoka, H., 2006. Spatial distribution of organic and sulfur geochemical parameters of oxic to anoxic surface sediments in Beppu Bay in southwest Japan. Estuar. Coast. Shelf Sci 72, $1-11$.

Krause, J.W., Nelson, D.M., Brzezinski, M.A., 2011. Biogenic silica production and the diatom contribution to primary production and nitrate uptake in the eastern equatorial Pacific Ocean. Deep Sea Res. Part II Top. Stud. Oceanogr. 58, 434-448.

Li, F.Y., Gao, S., Jia, J.J., Zhao, Y.Y., 2002. Contemporary deposition rates of fine grained sediment in the Bohai and Yellow Seas. Oceanol. Limnol. Sin. 33, 364-369 (in Chinese, with English abstract).

Lin, C.L., Su, J.L., Xu, B.R., Tang, Q.S., 2001. Long-term variations of temperature and salinity of the Bohai Sea and their influence on its ecosystem. Prog. Oceanogr. 49, 7-19.

Lin, T., Wang, L., Chen, Y., Tian, C., Pan, X., Tang, J., Li, J., 2014. Sources and preservation of sedimentary organic matter in the Southern Bohai Sea and the Yellow Sea: evidence from lipid biomarkers. Mar. Pollut. Bull. 86, 210-218.

McClelland, J.W., Valiela, I., 1998. Linking nitrogen in estuarine producers to landderived sources. Limnol. Oceanogr. 43, 577-585.

Meybeck, M., 1982. Carbon, nitrogen and phosphorus transport by World Rivers. Am. J. Sci. 282, 401-450.

Meyers, P.A., 1994. Preservation of elemental and isotopic source identification of sedimentary organic matter. Chem. Geol. 144, 289-302.

Meyers, P.A., 1997. Organic geochemical proxies of paleoceanographic, paleolimnlogic, and paleoclimatic processes. Org. Geochem. 27, 213-250.

Minoura, K., Hoshino, K., Nakamura, T., Wada, E., 1997. Late Pleistocene-Holocene paleoproductivity circulation in the Japan Sea: sea-level control on $\delta^{13} \mathrm{C}$ and $\delta^{15} \mathrm{~N}$ records of sediment organic material. Palaeogr. Palaeoclimatol. Palaeoecol $135,41-50$.

Pancost, R.D., Boot, C.S., 2004. The palaeoclimatic utility of terrestrial biomarkers in marine sediments. Mar. Chem. 92, 239-261.

Qiao, S.Q., Shi, X.F., Wang, G.Q., Yang, G., Hu, N.J., Liu, S.F., Liu, Y.G., Zhu, A.M., Li, C.X., 2010. Discussion on grain-size characteristics of seafloor sediment and transport pattern in the Bohai Sea. Acta Oceanol. Sin. 32, 139-147 (in Chinese, with English abstract).

Ramaswamy, V., Gaye, B., Shirodkar, P.V., Rao, P.S., Chivas, A.R., Wheeler, D., Thwin, S., 2008. Distribution and sources of organic carbon, nitrogen and their isotopic signatures in sediments from the Ayeyarwady (Irrawaddy) continental shelf, northern Andaman Sea. Mar. Chem. 111, 137-150.

Redfield, A.C., Ketchum, B.H., Richards, F.A., 1963. The influence of organisms on the composition of sea water. In: Hill, M.N. (Ed.), The Sea. Wiley, New York, pp. 26-77.

Ren, M.E., Shi, Y.L., 1986. Sediment discharge of the Yellow River (China) and its effect on the sedimentation of the Bohai and the Yellow Sea. Cont. Shelf Res 6, 785-810.

Ruttenberg, K.C., Goñi, M.A., 1997. Phosphorus distribution, C: N:P ratios, and $\delta^{13} \mathrm{C}$ in arctic, temperate, and tropical coastal sediments: tools for characterizing bulk sedimentary organic matter. Mar. Geol. 139, 123-145.

Savage, C., 2005. Tracing the influence of sewage nitrogen in a coastal ecosystem using stable nitrogen isotopes. Ambio 34, 145-150.

Shan, X., Sun, P., Jin, X., Li, X., Dai, F., 2013. Long-term changes in fish assemblage structure in the Yellow River estuary ecosystem, China. Mar. Coast. Fish 5 , $65-78$.

Shultz, D., Calder, J.A., 1976. Organic carbon ${ }^{13} \mathrm{C} /{ }^{12} \mathrm{C}$ variations in estuarine sediments. Geochim. Cosmochim. Acta 40, 381-385.

Su, J.L., 1998. Circulation dynamics of the China Seas north of $180^{\circ} \mathrm{N}$. In: Robinson, A.R., Brink, K.H. (Eds.), The Sea, vol. 11. John Wiley \& Sons Inc., New York, pp. 483-505.

Su, Z., Wang, Y., Dong, Z., Zhang, Y., Liu, D., 2015. Response of phytoplankton assemblages to the water sediment regulation in the adjacent sea of the Yellow River mouth. Acta Oceanol. Sin. 37, 62-75 (in Chinese, with English abstract).

Statistical Yearbook of Shandong province, 2010. Shandong Statistical Bureau. China statistics Press.

Tesi, T., Miserocchi, S., Goñi, M.A., Langone, L., Boldrin, A., Turchetto, M., 2007. Organic matter origin and distribution in suspended particulate materials and surficial sediments from the western Adriatic Sea (Italy). Estuar. Coast. Shelf Sci. 69, 225-245.

Thornton, S.F., McManus, J., 1994. Application of organic carbon and nitrogen stable isotope and $\mathrm{C} / \mathrm{N}$ ratios as source indicators of organic matter provenance in estuarine systems: evidence from the Tay Estuary, Scotland. Estuar. Coast. Shelf Sci. 38, 219-233. 
Tyson, R.V., 1995. Sedimentary Organic Matter. Chapman and Hall, London.

Voss, M., Deutsch, B., Elmgren, R., Humborg, C., Kuuppo, P., Pastuszak, M., Rolff, C. Schulte, U., 2006. Source identification of nitrate by means of isotopic tracers in the Baltic Sea catchments. Biogeosciences 3, 663-676.

Wan, Y., Hu, J., An, L., An, W., Yang, M., Mitsuaki, I., Tatsuya, H., Tao, S., 2005. Determination of trophic relationships within a Bohai Bay food web using stable $\delta^{15} \mathrm{~N}$ and $\delta^{13} \mathrm{C}$ analysis. Chin. Sci. Bull. 50, 1021-1025.

Wang, H., Yang, Z.S., Saito, Y., Liu, J.P., Sun, X.X., 2006. Interannual and seasonal variation of the Huanghe (Yellow River) water discharge over the past 50 years: connections to impacts from ENSO events and dams. Glob. Planet. Change 50, $212-225$.

Xia, B., Zhang, X., Cui, Y., Chen, B., Chen, J., Guo, F., Zhang, Y., Huang, C., 2009. Evaluation of the physicochemical environment and nutrition status in Laizhou Bay and adjacent waters in summer. Prog. Fish. Sci. 30, 103-111 (in Chinese, with English abstract).

Zhang, D., Yang W., Zhao, J., 2012. Tracing nitrate sources of the Yellow River and it tributaries with nitrogen isotope. J. Ecol. Rural Environ. 28, 622-627 (in Chinese, with English abstract).

Zhang, J., Wen, H.W., Chong, S.M., 1990. Huanghe (Yellow River) and its estuary: sediment origin, transport and deposition. J. Hydrol. 120, 203-223.

Zhang, J., Wu, Y., Jennerjahn, T.C., Ittekkot, V., He, Q., 2007. Distribution of organic matter in the Changjiang (Yangtze River) Estuary and their stable carbon and nitrogen isotopic ratios: implications for source discrimination and sedimentary dynamics. Mar. Chem. 106, 111-126.

Zhu, Y., Chang, R., 2000. Preliminary study of the dynamic origin of the distribution pattern of bottom sediments on the continental shelves of the Bohai Sea, Yellow Sea and East China Sea. Estuar. Coast. Shelf Sci 51, 663-680. 